\section{FOLGER LIBRARY ACQUIRES REFORMATION EDITIONS}

A collection of 850 early editions of the works of the Reformation has been acquired by the Folger Shakespeare Library. In announcing the purchase, $\mathrm{O}$. B. Hardison, Jr., said, "The addition of this magnificent collection to the extensive Reformation materials already in the library will make Washington one of the major international centers for Reformation studies." Elizabeth Niemeyer, acquisitions librarian, was responsible for locating the collection.

Assembled by the Swiss bibliophile and author Emanuel Stickelberger (1884-1962), the collection was offered exclusively to the Folger Library by the firm of Erasmushaus-Haus der Bucher, Basel. The accompanying catalog produced by the prestigious book firm states in its introduction that "the collection is incorporated as a whole into one of the world's greatest and most beautiful libraries, the Folger Shakespeare Library in Washington, D.C., where it will be a pleasure and a help to many more bibliophiles and scholars." In its field, this Reformation collection is considered to be "the most extensive and interesting collection of the twentieth century."

Of the 850 items in the collection, 700 are dated before 1551; of these, 516 were printed before 1531. The works include 180 original impressions of Martin Luther, most notably a first printing of the expanded version of the 95 Theses, Resolutiones disputationum ad Leonem $X$ (Basel, 1518). The collection includes the writings of Calvin, Zwingli, and other reformers as well as materials on debates and disputa- tions that took place during the period and numerous pamphlets by German supporters of the reform. Early Bibles, including a copy of the first French Protestant Bible (Neufchatel, 1535 ), and Psalters are to be found among the new volumes.

The volumes are extensively illustrated with woodcuts by early sixteenth-century German artists, such as Hans Holbein, Lucas Cranach, Hans Baldung Grien, Urs Graf, and Hans Weiditz. Many of the volumes are hand bound in modern quarter vellum, with covered boards made from incunabula leaves and with backstrip titles hand lettered in Gothic script. Others are bound in old vellum manuscripts.

Purchase funds for the collection had been contributed by an anonymous gift from a friend of the library and provided by grants from Crystal Trust of Wilmington, Delaware; from the National Endowment for the Humanities; and by the library's acquisition benefit.Folger Library Newsletter

\section{Library Newsletters Requested}

Editors of college and university library newsletters are requested to place the editor of College \& Research $\mathrm{Li}$ braries Neus on their mailing list. Permission to use items from newsletters (with a credit line) will be assumed unless we are otherwise notified. Librarians might also notify their Public Relations Offices to send us library-related items on a continuing basis.

I intend to submit a paper for the ACRL 1978 National Conference in Boston.

Name, Title, and Institutional Address

Telephone:

Tentative Title:

Attach a brief description of the proposed paper (no more than 200 words).

Return this statement of intent by November 30,1977 .

\author{
Mail to: \\ Irma $Y$. Johnson \\ Charles Hayden Memorial \\ Library \\ Massachusetts Institute of \\ Technology \\ Cambridge, MA 02139
}

